\title{
Preparation of mupirocin-loaded polymeric nanocapsules using essential oil of rosemary
}

\author{
Jaqueline Bandeira Rubenick ${ }^{1 *}$, Alexandre Machado Rubim ${ }^{1,2}$, Francieli Bellé ${ }^{1}$, Daniele Rubert \\ Nogueira-Librelotto ${ }^{1}$, Clarice Madalena Bueno Rolim ${ }^{1}$
}

\begin{abstract}
${ }^{1}$ Department of Industrial Pharmacy, Federal University of Santa Maria, Santa Maria, RS, Brazil, ${ }^{2}$ Laboratory Drug Quality Control, Franciscan University Center, Santa Maria, RS, Brazil
\end{abstract}

\begin{abstract}
The purpose of this study was to prepare and characterize mupirocin-loaded polymeric nanocapsules using two different oils and to develop and validate an analytical method for quantitative determination by high performance liquid chromatography. The mean size of the nanoparticles was $233.05 \mathrm{~nm}$ and 275.03 $\mathrm{nm}$ for nanocapsules with a rosemary oil like oily core and caprylic/capric triglyceride, respectively, and a good polydispersity index below 0.25 for both formulations. The nanocapsules showed good stability when stored at $40^{\circ} \mathrm{C}$ and room temperature for 30 days. The quantitative method was performed with a mobile phase consisting of ammonium ammonium acetate $(0.05 \mathrm{M}$ adjusted to $\mathrm{pH} 5.0$ with acetic acid) and acetonitrile $60: 40(\mathrm{v} / \mathrm{v})$; the flow rate was $0.8 \mathrm{~mL} / \mathrm{min}$, UV detection at $230 \mathrm{~nm}$. The analytical method was linear in the range of 5.0-15.0 $\mu \mathrm{g} / \mathrm{mL}$, specific for both oils, accurate, precise (intermediate precision $\mathrm{RSD}=1.68 \%$ and repeatability $\mathrm{RSD}=0.81 \%$ ) and robust under the evaluated conditions. Therefore, this method can be performed for quantification of mupirocin in polymeric nanocapsules containing both oils.
\end{abstract}

Uniterms: Mupirocin/High Performance Liquid Chromatography. Mupirocin/Polymeric nanocapsules. Rosemary oil.

\section{INTRODUCTION}

Mupirocin (MUP) is an antibiotic used to treat skin surface infections. It is highly effective against Staphylococcus and Streptococcus, and is utilized to control methicillin-resistant Staphylococcus aureus. The chemical structure consists of a chain of fatty acids loaded on monic acid by an ester type linkage that mimics the carbon skeleton of isoleucine, competing with this aminoacid for the active site of isoleucyl-tRNA bacterial synthetase, inhibiting bacterial protein synthesis. However, reports of increased resistance to mupirocin are a matter of concern (Martindale, 2011; Poovelikunnel, Gethin, Humphreys, 2015; Sutherland et al., 1985; Thomas et al., 2010).

MUP is a crystalline white powder, slightly soluble in water, freely soluble in acetone and dichloromethane. It is a strong acid with a pKa value 4.83 , presenting a

\footnotetext{
*Correspondence: J. B. Rubenick. Departamento de Farmácia Industrial. Universidade Federal de Santa Maria. Av. Roraima, 1000 - Prédio 26 - 97105-900 - Santa Maria - RS, Brasil. E-mail: jaquerubenick2@gmail.com
}

molecular formula $\mathrm{C}_{26} \mathrm{H}_{44} \mathrm{O}_{9}$, melting point about $77-78^{\circ} \mathrm{C}$ and a partition coefficient of 2.25 (British Pharmacopeia, 2012; Martindale, 2011; USP, 2012).

Recently, several studies have reported utilizing molecules with activity against microorganisms that are capable of forming biofilm in different places (Comin et al., 2016; Iannitelli et al., 2011; Jain et al., 2009; Maryam et al., 2015). Along these lines, MUP-loaded polymeric nanocapsules were developed by our research group in an attempt to increase the activity of MUP against Staphylococcus aureus.

Nanocapsules are vesicular systems in which the drug is confined to a cavity surrounded by a single polymer. These systems present a particle size less than $1 \mu \mathrm{m}$. They have the capacity to control the drug release profile, increase the stability of drugs during storage and provide vectoring through organs and cells (Couvreur et al., 2002; Schaffazick et al., 2003, Zili, Sfar, Fessi, 2005).

In order to ensure reliable and interpretable information about a sample, the analytical methods must first be validated. The validation of the analytical method is a continuous process that starts by planning an analytical 
and continuous strategy throughout the development period (Ribani et al., 2004).

Some analytical methods have been described in the literature for the determination of MUP in pharmaceutical formulations, liposomal hydrogels, and penetrations studies (Berg, 2011; Echevarría et al., 2003; Jagota et al., 1992; Shailesh, Kulkarni, 2014). Official techniques for quality control of MUP in raw material, cream, ointment and, nasal ointment are described in the United States Pharmacopeia (USP, 2012) and British Pharmacopeia (2012).

Due to the lack of a methodology for the determination of MUP in polymeric nanocapsules, this study aimed to develop and validate a method for the determination of MUP in polymeric nanocapsules containing essential oil of rosemary and caprylic/capric triglyceride, as well as to study the stability and the physical-chemical properties of the different formulations).

\section{MATERIAL AND METHODS}

\section{Reagents and materials}

MUP with $100.0 \%$ purity standard substance was obtained from The United States Pharmacopeia, batch G0M003. The MUP raw material batch: 15537/2014 (purity 96.9\%) was kindly supplied by Cristália ${ }^{\circledR}$. The polymeric nanocapsule excipients were: $\operatorname{poly}(\varepsilon-$ caprolactone) (PCL, MW: 70000-90000) and sorbitan monostearate $60\left(\operatorname{Span}^{\circledR} 60\right)$ which were purchased from Sigma-Aldrich ${ }^{\circledR}$ (São Paulo, Brazil), essential oil of rosemary was purchased from Petite Marie ${ }^{\circledR}$ (Itaquaquecetuba, Brazil), caprylic/capric triglyceride (Crodamol ${ }^{\circledR}$ GTCC) from Alpha Química ${ }^{\circledR}$ (Porto Alegre, Brazil), polysorbate 80 (Tween ${ }^{\circledR} 80$ ) purchase from Synth ${ }^{\circledR}$ and acetone from Synth ${ }^{\circledR}$. All other reagents and solvents used were of analytical grade.

\section{Instrumentation and chromatography conditions}

The apparatus used for the LC analysis was a Shimadzu ${ }^{\circledR}$ system (Kyoto, Japan), equipped with an LC20AT pump, SIL-20A ht auto sampler, CTO-20AC column oven, SPD-M20A PDA detector, CBM-20A system controller, and LC solution software was used to quantify the samples. The Ultra Basic Denver potentiometer was used to determine the $\mathrm{pH}$ of all solutions. Chromatography separations were achieved using the modified method of the British Pharmacopeia (2012). The separations were performed with a Merck ${ }^{\circledR} \mathrm{C} 18$ column $(250 \mathrm{~mm}$ x 4.6 $\mathrm{mm}, 5 \mu \mathrm{m})$ at $25^{\circ} \mathrm{C}$. The mobile phase composition was ammonium acetate $(0.05 \mathrm{M}$ adjusted to $\mathrm{pH} 5.0$ with acetic acid) and acetonitrile 60:40 (v/v). The flow rate was 0.8 $\mathrm{mL} / \mathrm{min}$, the UV detection was set at $230 \mathrm{~nm}$ and the injected volume was $10 \mu \mathrm{L}$.

\section{Development and characterization of polymeric nanocapsules containing mupirocin}

Before polymeric nanocapsules were developed, drug solubility had to be studied in two different oils. Briefly, an excess amount of MUP was transferred to an individual erlenmeyer containing $2 \mathrm{~mL}$ of each oil. The flasks were covered and shaken at $120 \mathrm{rpm}$ in an orbital incubator (Novatecnica ${ }^{\circledR}$, NT712) for 24 hours at $37 \pm 0.5^{\circ} \mathrm{C}$. After equilibrium, samples were centrifuged at $4000 \mathrm{rpm}$ for 10 minutes, and then the concentration of MUP in oil was determined by the HPLC method described above.

Polymeric nanocapsules containing MUP were prepared by nanoprecipitation of pre-formed polymers (Fessi et al., 1989). The organic phase was constituted by PCL $(100.0 \mathrm{mg})$, sorbitan monostearate 60 (76.6 $\mathrm{mg})$, essential oil of rosemary $(330.0 \mathrm{mg})$ and mupirocin $(10.0 \mathrm{mg})$ dissolved in acetone $(27.0 \mathrm{~mL})$. This organic phase was added with moderate magnetic stirring into an aqueous phase constituted by the polysorbate 80 (76.6 $\mathrm{mg}$ ) dissolved in water $(55.0 \mathrm{~mL})$. The aqueous phase quickly turned milky with bluish opalescence due to the formation of the nanoparticles. After nanoprecipitation, the acetone and a part of water were removed in a rotary evaporator and the nanoparticles were concentrated to a final volume of $10 \mathrm{~mL}(1.0 \mathrm{mg} / \mathrm{mL}$ of MUP). This formulation was called polymeric nanocapsules of mupirocin and rosemary (NCMR). The polymeric nanocapsules containing caprylic/capric triglyceride were prepared using the same procedure, but the core oil was formed by caprylic/capric triglyceride (330.0 $\mathrm{mg}$ ). Thus, the given name of this formulation was polymeric nanocapsules of mupirocin and caprylic/capric triglyceride (NCMT).

The unloaded nanocapsules of rosemary oil and caprylic/capric triglyceride were called BNCR and BNCT, respectively. These formulations were prepared by the same method but without adding the drug.

\section{Characterization of polymeric nanocapsules}

Particle-size, zeta potential and $p H$ : the zeta potential and particle-size distribution of the formulations were determined by Zetasizer Nano ZS ${ }^{\circledR}$ (Nanoseries, Malvern, UK). In both determinations, samples were 
diluted in Milli-Q water. The $\mathrm{pH}$ values were determined by an Ultra Basic Denver ${ }^{\circledR}$ potentiometer calibrated with $\mathrm{pH} 4.0$ and 7.0 solutions. The nanoparticles were analyzed directly on the electrode. The reported results are the mean values obtained after analyzing three batches of each formulation.

\section{Determination of drug content and encapsulation efficiency}

For the analysis of drug from nanocapsules, a quantity equivalent to $1000 \mu \mathrm{g}$ of drug was transferred to a $10 \mathrm{~mL}$ volumetric flask and dispersed in acetonitrile. To optimize the extraction method the volumetric flasks were kept under sonication for $15 \mathrm{~min}$. Then a $1.0 \mathrm{~mL}$ aliquot was pipetted into a $10 \mathrm{~mL}$ volumetric flask and diluted with the same solvent. The samples were then filtered using a nylon membrane with $0.45 \mu \mathrm{m}$ porosity. The analysis was performed using the previously developed HPLC method.

To determine the encapsulation efficiency 300 $\mu \mathrm{L}$ of each formulation were placed in Amicon Ultra ${ }^{\circledR}$ filters and centrifuged at $10000 \mathrm{rpm}$ for 15 minutes. The encapsulation efficiency was calculated by the difference between the total drug content and the drug content found in the ultrafiltrate.

\section{Stability evaluation}

The different nanoparticles were kept at room temperature and at $40^{\circ} \mathrm{C}$ for 30 days. The effects of storage time $(0,15$ and 30 days $)$ on the $\mathrm{pH}$, particle size, zeta potential, drug content and encapsulation efficiency were determined. The stability studies were performed in three different batches of each formulation.

\section{Development and validation of the HPLC method}

The method was validated according to the official guidelines (ANVISA, 2003; ICH, 2005; INMETRO, 2007). The parameters evaluated were: specificity, linearity, precision, accuracy, robustness, detection and quantification limits. The polymeric nanocapsules (NCMR) were used to develop this method.

\section{Specificity}

Method specificity was assessed using a standard solution containing MUP, samples of MUP-loaded polymeric nanocapsules (NCMR and NCMT) and nanoparticles without MUP (BNCR and BNCT).
Moreover, the specificity was evaluated for stress testing (ICH, 2005). All the samples were analyzed in triplicate. The stress conditions follow:

Hydrolytic conditions: $10 \mathrm{mg}$ of MUP reference substance were dissolved in a $10 \mathrm{~mL}$ volumetric flask with acetonitrile. Then, a $1 \mathrm{~mL}$ aliquot was transferred to a $10 \mathrm{~mL}$ volumetric flask and dissolved in $\mathrm{HCl} 0.1 \mathrm{M}$ and $\mathrm{NaOH} 0.1 \mathrm{M}$. After 24 hours, the samples were neutralized and analyzed.

Photolytic degradation: $10 \mathrm{mg}$ of MUP reference substance were dissolved in a $10 \mathrm{~mL}$ volumetric flask with acetonitrile. Next, a $1 \mathrm{~mL}$ aliquot was transferred to a $10 \mathrm{~mL}$ volumetric flask and dissolved with acetonitrile. This solution was exposed to UV light $(K=254 \mathrm{~nm})$ for 24 hours. Then, a $1 \mathrm{~mL}$ aliquot was transferred to a $10 \mathrm{~mL}$ volumetric flask and dissolved with acetonitrile.

Oxidative condition: $10.0 \mathrm{mg}$ of MUP reference substance were dissolved in a $10 \mathrm{~mL}$ volumetric flask with acetonitrile. After that, a $1 \mathrm{~mL}$ aliquot was transferred to a $10 \mathrm{~mL}$ volumetric flask and dissolved in hydrogen peroxide $3 \%$. After, 24 hours, a $1 \mathrm{~mL}$ aliquot was transferred to a $10 \mathrm{~mL}$ volumetric flask and dissolved in acetonitrile.

Temperature condition: $10 \mathrm{mg}$ of MUP reference substance were dissolved in a $10 \mathrm{~mL}$ volumetric flask with acetonitrile. Then, a $1 \mathrm{~mL}$ aliquot was transferred to a $10 \mathrm{~mL}$ volumetric flask and dissolved with acetonitrile. This solution was exposed at $40{ }^{\circ} \mathrm{C}$. After 24 hours, a $1 \mathrm{~mL}$ aliquot was transferred to a $10 \mathrm{~mL}$ volumetric flask and dissolved in acetonitrile.

\section{Linearity and detection and quantification limits}

Linearity was determined by constructing three independent analytical curves $(n=3)$ with five linear concentrations of MUP (5.0, 8.0, 10.0, 12.0 and $15.0 \mu \mathrm{g} / \mathrm{mL}$ ). All concentrations were diluted in acetonitrile and analyzed in triplicate on three consecutive days. The results were assessed by regression analysis using the least squares method to calculate the calibration curves. The detection and quantification limits were determined using an average standard curve, considering the intercept standard deviation and slope.

\section{Precision}

Precision was investigated with respect to repeatability (intra-day) and intermediate precision (inter-day). Repeatability was assessed by assaying the concentrations of 5.0, 10.0 and $15.0 \mu \mathrm{g} / \mathrm{mL}$, in triplicate during the same day, by the same analyst and using 
the same instrumentation. Intermediate precision was assessed by carrying out the same analysis on 3 different days, with different instrumentation and analyst. This parameter was expressed as \% of relative standard deviation (RSD).

\section{Accuracy (Recovery method)}

Accuracy was evaluated at concentration levels of 80,100 and $120 \%$ where a known amount of MUP standard solution was added to sample solution. The theoretical and the measured concentration were then compared. The experiments were repeated three times.

\section{Robustness}

Robustness was evaluated using the method proposed by Youden, Steiner (1975). Small variations were induced in the nominal values of the method. The four parameters and the variations variations introduced are shown in Table I. Then, eight runs were performed to determine the influence of each parameter on the final results. According to Nogueira et al. (2011), this method will be robust if conditions 1 and 2 are met:

Condition 1: (for factor A and other factors) content of MUP $-5 \% \leq \mathrm{A} \leq$ content of MUP $+5 \%$.

Condition 2: (for factor $\mathrm{A}$ and other factors) $\mathrm{A}-\mathrm{a} \leq$ $3 \%$ involving the MUP content.

An aliquot of each sample was transferred into an individual $10 \mathrm{~mL}$ volumetric flask, diluted to volume with acetonitrile, and filtered through a nylon membrane with $0.45 \mu \mathrm{m}$ porosity, obtaining the final MUP concentration of $10.0 \mu \mathrm{g} / \mathrm{mL}$. The concentrations of MUP presented in samples were determined from the analytical curve.

\section{System suitability}

System suitability was evaluated by five replicate analyses of MUP reference substance at a concentration of $10 \mu \mathrm{g} / \mathrm{mL}$. The parameters assessed were: number of theoretical plates and tailing factor.

\section{Statistical analysis}

All tests were performed in 3 replicates and the results were expressed as average \pm standard deviation. The results were submitted to (ANOVA) followed by Tukey test at a significance level of 5\%.

\section{RESULTS AND DISCUSSION}

\section{Development and optimization of the method}

The development of safe, reliable analytical methods is a very important tool for the quality control of pharmaceutical products and raw material. The chromatography technique is a good alternative for performing analysis of drug from nano-based formulations, since it is necessary to have a total separation of the drug from the formulation components (Harter et al., 2014).

Based on the official method (British Pharmacopoeia, 2012), some chromatography conditions were evaluated to optimize this method. Firstly, a mobile phase was tested containing a mixture of methanol and water $(75: 25 \mathrm{v} / \mathrm{v})$, however, it was not stable at baseline. Another mixture tested was methanol and water pH $5.0(60: 40 \mathrm{v} / \mathrm{v})$, but this condition affected the retention time and shape of the MUP peak. Similar results were shown by Amrutiya, Madan, Bajaj (2010) when researching the simultaneous quantification of prednicarbate, MUP and ketoconazole in topical dosage form. In this work several eluent mixtures and $\mathrm{pH}$ values were evaluated to obtain a good separation.

\section{System suitability}

To obtain the best chromatographic method, the mobile phase was composed by ammonium acetate $(0.05 \mathrm{M}$, adjusted to $\mathrm{pH} 5.0$ with acetic acid) and acetonitrile $60: 40$ $(\mathrm{v} / \mathrm{v})$, with a flow rate of $0.8 \mathrm{~mL} / \mathrm{min}$. These conditions were utilized to provide an adequate peak and satisfactory results according to criteria evaluated. Five replicates of MUP reference substance were evaluated at a concentration of $10 \mu \mathrm{g} / \mathrm{mL}$. After chromatogram analysis, the number of

TABLE I - Parameters and variations to evaluate the robustness of the chromatography method

\begin{tabular}{lcc}
\hline Parameter & & Variations \\
\hline Mobile phase rate (mL/min) & $\mathrm{A}-1.0$ & $\mathrm{a}-0.6$ \\
$\begin{array}{l}\text { Acetonitrile concentration in mobile phase (\%) } \\
\text { Sonication time for extraction }\end{array}$ & $\mathrm{B}-42$ & $\mathrm{~b}-38$ \\
$\begin{array}{l}\text { of drug (minutes) } \\
\text { Column supplier }\end{array}$ & $\mathrm{C}-20$ & $\mathrm{c}-10$ \\
\hline
\end{tabular}


theoretical plates and tailing factor were determined. The average values obtained were 4628 and 1.19 , respectively.

\section{Specificity}

The chromatograms (Figure 1) obtained during the specificity test showed that none of the formulation excipients were eluted in the same retention time as the MUP peak.

Furthermore, the interference of potential degradation products was investigated through a forced degradation test. These studies were performed to identify the factors that would affect the drug stability. Usually the range of degradation is $10 \%$ to $30 \%$ (Chan et al., 2004).

After evaluation of stress conditions (temperature $40{ }^{\circ} \mathrm{C}$ and oxidative $3 \%$ ), the concentration remained constant and no possible degradation product of the MUP reference substance was found. In acid and basic hydrolysis, as well as under photolytic conditions (Figure 2 ) the residual drug content after 24 hours was $10.23 \%$, $6.76 \%$ and $16.93 \%$, respectively in relation to the value obtained in the initial analysis.

In the chromatograms obtained after acid and basic hydrolysis, the formation of possible degradation products can be seen at about 3 min and 7 min, respectively.

\section{Linearity}

According to Figure 3, the linearity was observed over the concentration range of 5.0 to $15.0 \mu \mathrm{g} / \mathrm{mL}$, and the analytical curve equation obtained was $\mathrm{y}=18386 \mathrm{x}-$ 9906 (where, $\mathrm{x}$ is concentration and $\mathrm{y}$ is the peak absolute area). The statistical analysis showed significant linear regression $\left(\mathrm{F}_{\mathrm{cal}}=6171.664>\mathrm{F}_{\mathrm{tab}}=4.96\right)$ and no significant deviation from linearity $\left(\mathrm{F}_{\mathrm{cal}}=2.0031<\mathrm{F}_{\mathrm{tab}}=3.71\right)$.

The quantification and detection limits were $1.68 \mu \mathrm{g} / \mathrm{mL}$ and $0.56 \mu \mathrm{g} / \mathrm{mL}$, respectively demonstrating the sensibility of the method for low concentrations.

\section{Precision}

This parameter was evaluated as intermediate precision and repeatability and was expressed as relative standard deviation (RSD \%). Accordingly, Tables II and III show the mean RSD values of $1.68 \%$ and $0.69 \%$, respectively, indicating the method precision over the concentration range. The limit recommended for this evaluation is RSD less than 5\% (ANVISA, 2003).

\section{Accuracy (Recovery method)}

Three concentration levels and three replicates of each concentration were used to determine accuracy. The average percentage obtained was $98.85 \%-101.39 \%$ satisfying the acceptance criteria between $98.0 \%$ and $102.0 \%$ for this study (Shabir, 2003).

\section{Robustness}

The method described by Youden, Steiner (1975), makes it possible not only to evaluate method robustness, but also to sort the variation of each parameter in the final results. According to Tables IV and V, the values showed satisfactory robustness of the method.

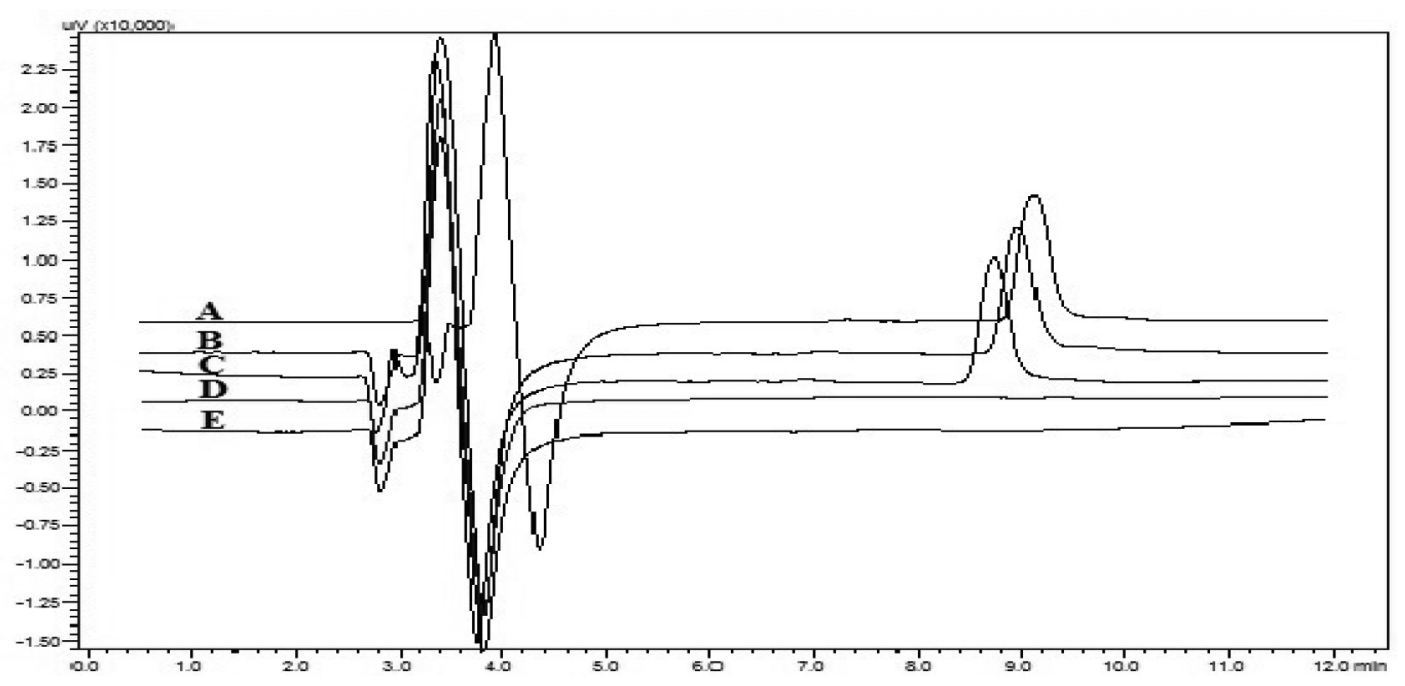

FIGURE 1 - Chromatograms corresponding to: (A) solution of MUP reference substance, (B) Nanocapsules of MUP and caprylic/ capric triglyceride oil, (C) Nanocapsules of MUP and rosemary oil, (D) Unloaded nanocapsules of rosemary oil and (E) unloaded nanocapsules of caprylic/capric triglyceride oil. 

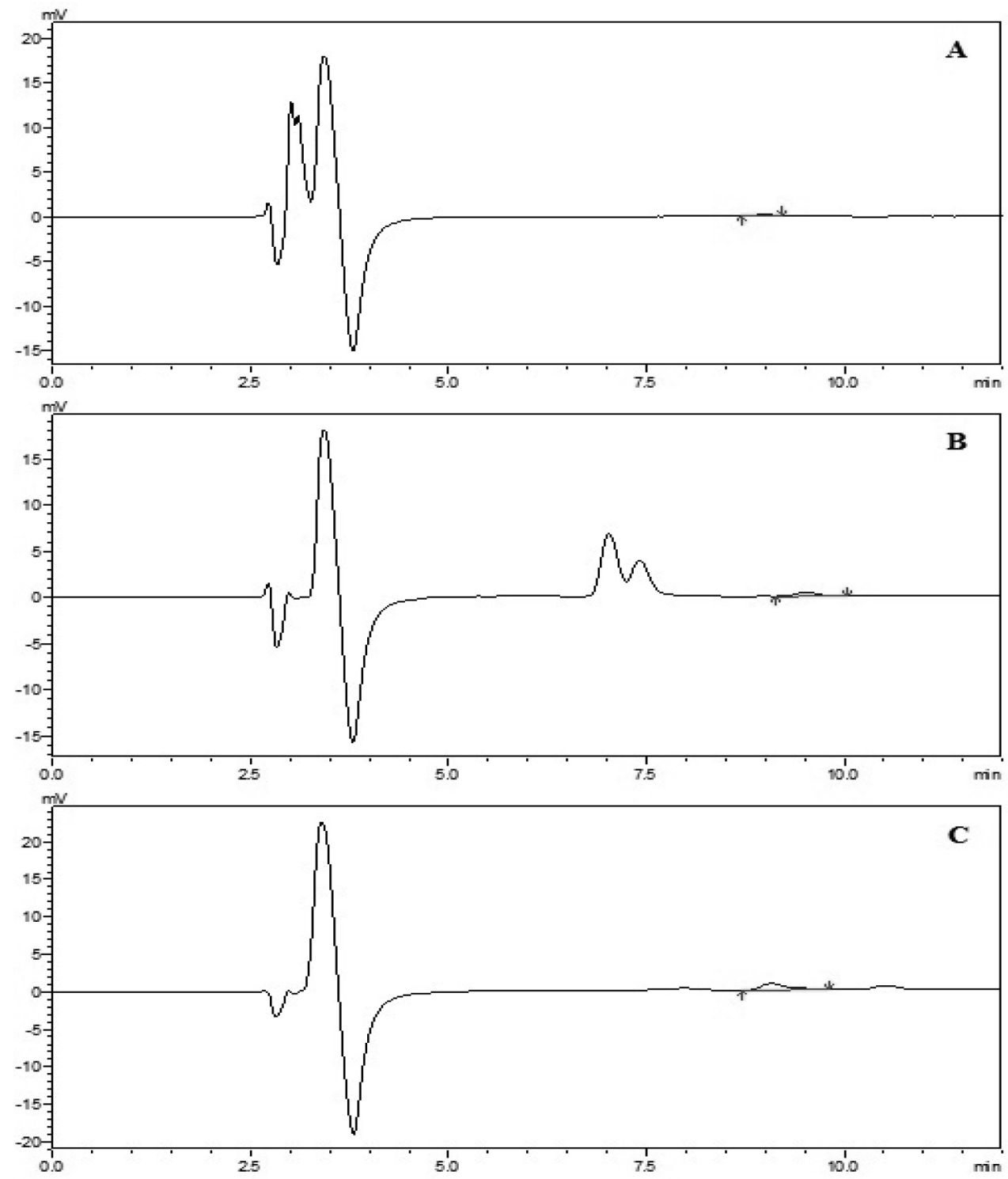

FIGURE 2 - Chromatograms corresponding to: (A) solution of MUP time 24 hours after acid hydrolysis, (B) solution of MUP time 24 hours after basic hydrolysis and (C) solution of MUP time 24 hours after photolytic conditions.

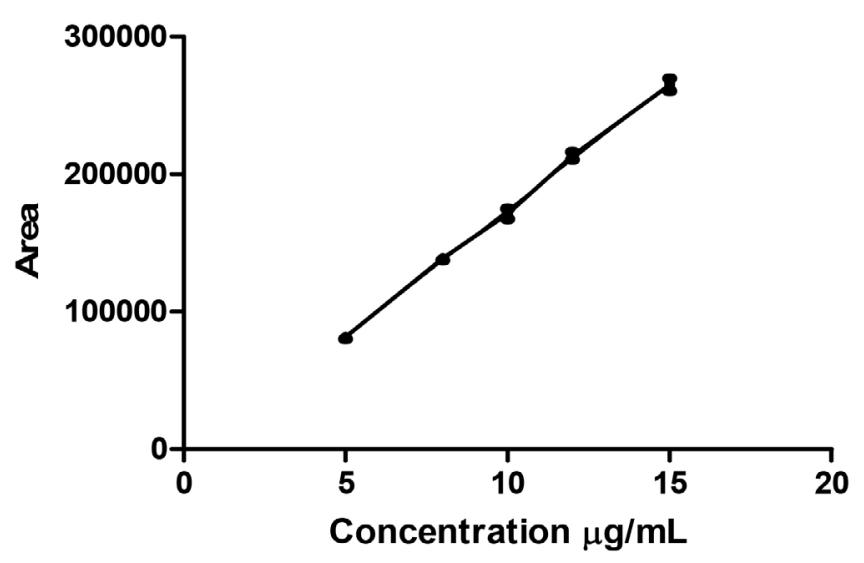

FIGURE 3 - Analytical curve of MUP.
The variation of some method parameters did not change the MUP content in the sample significantly. The results meet conditions 1 and 2, and were therefore considered a robust method for the determination of MUPloaded polymeric nanocapsules.

\section{Preparation and characterization of polymeric nanocapsules}

Blank formulations and MUP-loaded polymeric nanocapsules were prepared through a nanoprecipitation technique. Table VI summarizes some physical-chemical characteristics after preparation of formulations containing the different oils. 
TABLE II - Values obtained for the intermediate precision determination for MUP-loaded polymeric nanocapsules with rosemary oil

\begin{tabular}{llcccc}
\hline Day & N & Analyst 1 & Analyst 2 & Average \pm SD & RSD (\%) \\
\hline \multirow{2}{*}{1} & 1 & 98.89 & 96.16 & & \\
& 2 & 99.98 & 99.68 & $98.69 \pm 1.371$ & 1.39 \\
2 & 3 & 99.10 & 98.33 & & \\
& 1 & 99.13 & 97.71 & & 1.86 \\
& 2 & 103.20 & 100.06 & $99.92 \pm 1.858$ & 1.78 \\
3 & 3 & 100.38 & 99.04 & & \\
& 1 & 100.59 & 101.24 & & $100.59 \pm 1.791$ \\
\hline Average content (\%) & 2 & 100.80 & 102.48 & & 1.68 \\
Average RSD (\%) & 3 & 97.19 & 101.22 & & \\
\hline
\end{tabular}

RSD - relative standard deviation. SD - standard deviation.

TABLE III - Values obtained for the repeatability determination for MUP-loaded polymeric nanocapsules with rosemary oil

\begin{tabular}{|c|c|c|c|}
\hline Sample concentration $\mu \mathrm{g} / \mathrm{mL}$ & Drug content (\%) & Average \pm SD & RSD (\%) \\
\hline & 98.38 & & \\
\hline \multirow[t]{3}{*}{5} & 98.42 & $98.49 \pm 0.1629$ & 0.17 \\
\hline & 98.68 & & \\
\hline & 97.98 & & \\
\hline \multirow[t]{3}{*}{10} & 98.80 & $97.92 \pm 0.9063$ & 0.93 \\
\hline & 96.99 & & \\
\hline & 98.56 & & \\
\hline \multirow[t]{2}{*}{15} & 100.04 & $98.94 \pm 0.9640$ & 0.97 \\
\hline & 98.23 & & \\
\hline
\end{tabular}

Average content (\%)

$98.45 \pm 0.5112$

Average RSD (\%)

0.69

$\mathrm{RSD}$ - relative standard deviation. SD - standard deviation.

TABLE IV - Combinations tested to evaluate the robustness, evaluating condition 1

\begin{tabular}{lcccccccc}
\hline \multicolumn{10}{c}{ Combination assay } \\
\hline Results & $\mathbf{s}$ & $\mathbf{t}$ & $\mathbf{u}$ & $\mathbf{v}$ & $\mathbf{w}$ & $\mathbf{x}$ & $\mathbf{y}$ & $\mathbf{z}$ \\
\hline Content $(\%)$ & 98.73 & 99.04 & 99.61 & 100.02 & 99.51 & 98.52 & 99.19 & 99.05 \\
Average content (\%) & 99.21 & & & & & & & \\
RSD (\%) & 0.49 & & & & & & & \\
\hline A & & & & & & & & \\
\hline
\end{tabular}

Acceptable range for content of mupirocin (\%)

$94.74 \% \leq 99.73^{b} \leq 104.72 \%$

${ }^{a}$ average of three determinations. ${ }^{b}$ value obtained of intermediate precision. RSD - relative standard deviation.

Before preparing the nanocapsules, the drug solubility was determined between different oils. The solubilities of MUP in rosemary oil and caprylic/capric triglyceride were $263.8 \mathrm{mg} / \mathrm{mL}$ and $54.3 \mathrm{mg} / \mathrm{mL}$ respectively. All the formulations presented particle sizes lower than $300 \mathrm{~nm}$ with a good monomodal distribution profile. The particle sizes were $233.05 \pm 1.94 \mathrm{~nm}$ and $280.13 \pm 2.91 \mathrm{~nm}$ for the nanocapsules with rosemary oil and caprylic/capric 
TABLE V - Combinations tested to evaluate the robustness, evaluating condition 2

\begin{tabular}{|c|c|c|c|c|}
\hline \multicolumn{2}{|c|}{ Content of mupirocin $(\%)$} & \multirow{2}{*}{$\begin{array}{c}\text { Difference (\%) } \\
\mathrm{A}-\mathrm{a}=0.28\end{array}$} & \multicolumn{2}{|c|}{$\begin{array}{c}\text { Limits for the difference } \\
(3 \% * 99.73 \%)\end{array}$} \\
\hline$A=99.35$ & $\mathrm{a}=99.07$ & & 2.99 & \\
\hline $\mathrm{B}=98.95$ & $b=99.47$ & $B-b=-0.52$ & 2.99 & \\
\hline $\mathrm{C}=99.26$ & $c=99.16$ & $\mathrm{C}-\mathrm{c}=0.10$ & 2.99 & Robust \\
\hline $\mathrm{D}=99.00$ & $d=99.42$ & $D-d=-0.42$ & 2.99 & \\
\hline$E=98.98$ & $\mathrm{e}=99.44$ & $E-e=-0.46$ & 2.99 & \\
\hline
\end{tabular}

Average content (\%): 99.21

SD: 0.2031

RSD (\%): 0.2

${ }^{a}$ value of intermediate precision obtained. SD - standard deviation. RSD - relative standard deviation.

TABLE VI - Physical-chemical characteristics of nanocapsules of MUP and rosemary oil (NCMR), nanocapsules of MUP and caprylic/capric triglyceride oil (NCMT), unloaded nanocapsules of rosemary (BNCR) and unloaded nanocapsules of caprylic/ capric triglyceride (BNCT)

\begin{tabular}{|c|c|c|c|c|c|}
\hline Samples & $\begin{array}{l}\text { Mean size }{ }^{\mathrm{b}} \\
\pm \text { S.D. }(\mathrm{nm})\end{array}$ & $\zeta$-Potential ${ }^{\mathrm{b}}(\mathrm{mV})$ & $\mathbf{p H}^{\mathbf{b}}$ & $\begin{array}{c}\text { Encapsulation } \\
\text { Efficiency } \\
(\% \mathbf{w} / \mathbf{w})\end{array}$ & $\begin{array}{l}\text { Drug content }^{\mathrm{b}} \\
\pm \text { S.D. }(\%)\end{array}$ \\
\hline NCMR & $233.05 \pm 1.94(0.25)^{\mathrm{a}}$ & -33.44 & $4.5 \pm 0.78$ & 97.46 & $100.50 \pm 0.15$ \\
\hline BNCR & $213.00 \pm 2.66(0.22)^{\mathrm{a}}$ & -33.97 & $5.6 \pm 1.08$ & ----- & ------ \\
\hline NCMT & $275.03 \pm 2.91(0.22)^{\mathrm{a}}$ & -32.21 & $4.4 \pm 0.84$ & 84.61 & $99.20 \pm 0.10$ \\
\hline $\mathrm{BNCT}$ & $229.77 \pm 1.72(0.19)^{\mathrm{a}}$ & -31.10 & $5.8 \pm 0.19$ & ----- & ------ \\
\hline
\end{tabular}

${ }^{\mathrm{a}}$ polydispersity index. ${ }^{\mathrm{b}}$ values represent the average between the 3 batches.

triglyceride oil, respectively. The polydispersity index (PDI) found was 0.25 and 0.22 indicating a uniform system size for both formulations. Similar results have been reported for essential oil of rosemary when prepared by the nanoprecipitation method (Ephrem et al., 2014). A PDI value lower than 0.5 is appropriate for colloidal suspension, indicating that the distribution size of the nanocapsules is homogeneous (Kumar et al., 2015; Wu, Zhang, Watanabe, 2011).

The $\mathrm{pH}$ values for NCMR and NCMT were 4.5 and 4.4, however for BNCR and BNCT the $\mathrm{pH}$ values were 5.6 and 5.8. These values can be justified by the acidic nature of the drug and due to the utilization of PCL around the core oil. In general, the $\mathrm{pH}$ values of the polymeric nanocapsules can vary from 3.0 to 7.5 when prepared according to the nanoprecipitation method (Mora-Huertas, Fessi, Elaissari, 2010).

Mupirocin was quantified after 15 min of extraction using acetonitrile as solvent. The average drug content in different formulations was $100.05 \pm 0.15 \%$ (NCMR) and $99.2 \pm 0.10 \%$ (NCMT).

\section{Stability evaluation}

In order to evaluate the stability of MUP-loaded polymeric nanocapsules, the formulations containing the drug and unloaded nanocapsules were stored at room temperature and at $40{ }^{\circ} \mathrm{C}$ for 30 days. The stability was evaluated by comparing the initial particle size, zeta potential, $\mathrm{pH}$, encapsulation efficiency and drug content with those obtained after 30 days (Table VII).

After 30 days of storage at room temperature and $40^{\circ} \mathrm{C}$, considering the average particle size, all formulation exhibited a similar characteristic when compared to the formulation at the initial time $(\mathrm{p}>0.05)$. After 30 days of storage at $40^{\circ} \mathrm{C}$, the $\mathrm{pH}$ values were significantly reduced in all formulations compared to the formulation at the initial time $(\mathrm{p}<0.05)$. This can be explained by the higher temperature, promoting increased polyester rates of hydrolysis and a reduction of the $\mathrm{pH}$ values and acidic characteristic of the drug (Mallin et al., 1996).

The MUP-loaded polymeric nanocapsules and unloaded nanocapsules exhibited a similar zeta potential 
TABLE VII - Physical-chemical characteristics after stability test of polymeric nanocapsules at room temperature and $40{ }^{\circ} \mathrm{C}$

\begin{tabular}{|c|c|c|c|c|c|c|c|c|c|c|}
\hline \multirow{2}{*}{$\begin{array}{l}\text { Samples } \\
15 \text { days } \\
\end{array}$} & \multicolumn{2}{|c|}{$\begin{array}{l}\text { Mean size } \\
\pm \mathrm{SD}(\mathrm{nm})\end{array}$} & \multicolumn{2}{|c|}{$\zeta$-Potential $^{\mathrm{b}}(\mathrm{mV})$} & \multicolumn{2}{|c|}{$\mathbf{p H}^{\mathrm{b}}$} & \multicolumn{2}{|c|}{$\begin{array}{c}\text { Encapsulation } \\
\text { efficiency }^{b} \\
(\% \text { w/w })\end{array}$} & \multicolumn{2}{|c|}{$\begin{array}{l}\text { Drug content }{ }^{b} \\
\quad \pm S D(\%)\end{array}$} \\
\hline & $25^{\circ} \mathrm{C}$ & $40^{\circ} \mathrm{C}$ & $25^{\circ} \mathrm{C}$ & $40^{\circ} \mathrm{C}$ & $25^{\circ} \mathrm{C}$ & $40^{\circ} \mathrm{C}$ & $25^{\circ} \mathrm{C}$ & $40^{\circ} \mathrm{C}$ & $25^{\circ} \mathrm{C}$ & $40^{\circ} \mathrm{C}$ \\
\hline NCMR & $\begin{array}{l}238.56 \\
\pm 0.21\end{array}$ & $\begin{array}{l}238.05 \\
\pm 1.08\end{array}$ & $\begin{array}{l}-33.7 \\
\pm 1.85\end{array}$ & $\begin{array}{l}-24.1 \\
\pm 1.02\end{array}$ & $\begin{array}{c}4.4 \\
\pm 0.12\end{array}$ & $\begin{array}{c}4.1 \\
\pm 0.11\end{array}$ & 97.10 & 95.53 & $\begin{array}{l}99.51 \\
\pm 0.24\end{array}$ & $\begin{array}{c}97.92 \\
\pm 0.14\end{array}$ \\
\hline BNCR & $\begin{array}{l}221.02 \\
\pm 0.14\end{array}$ & $\begin{array}{l}210.89 \\
\pm 1.58\end{array}$ & $\begin{array}{c}-30.2 \\
\pm 1.08\end{array}$ & $\begin{array}{l}-20.7 \\
\pm 1.77\end{array}$ & $\begin{array}{c}5.4 \\
\pm 0.06\end{array}$ & $\begin{array}{c}4.4 \\
\pm 0.14\end{array}$ & ------ & ------ & ------ & ------ \\
\hline NCMT & $\begin{array}{c}268.8 \\
\pm 0.84\end{array}$ & $\begin{array}{l}279.93 \\
\pm 1.26\end{array}$ & $\begin{array}{c}-30.4 \\
\pm 0.88\end{array}$ & $\begin{array}{c}-28.2 \\
\pm 1.08\end{array}$ & $\begin{array}{c}4.5 \\
\pm 0.14\end{array}$ & $\begin{array}{c}3.8 \\
\pm 0.09\end{array}$ & 83.19 & 82.48 & $\begin{array}{c}98.90 \\
\pm 0.21\end{array}$ & $\begin{array}{l}97.50 \\
\pm 0.37\end{array}$ \\
\hline $\mathrm{BNCT}$ & $\begin{array}{l}224.53 \\
\pm 0.15 \\
\end{array}$ & $\begin{array}{l}234.21 \\
\pm 0.19 \\
\end{array}$ & $\begin{array}{r}-32.8 \\
\pm 1.21 \\
\end{array}$ & $\begin{array}{r}-28.5 \\
\pm 1.78 \\
\end{array}$ & $\begin{array}{c}5.7 \\
\pm 0.17 \\
\end{array}$ & $\begin{array}{c}4.5 \\
\pm 0.11 \\
\end{array}$ & ------ & ------ & ------ & ------ \\
\hline \multicolumn{11}{|l|}{30 days } \\
\hline NCMR & $\begin{array}{l}235.42 \\
\pm 0.64\end{array}$ & $\begin{array}{l}241.03 \\
\pm 1.29\end{array}$ & $\begin{array}{l}-31.53 \\
\pm 0.78\end{array}$ & $\begin{array}{l}-25.20 \\
\pm 1.02\end{array}$ & $\begin{array}{c}4.48 \\
\pm 0.07\end{array}$ & $\begin{array}{c}3.67 \\
\pm 0.18\end{array}$ & 98.83 & 96.02 & $\begin{array}{l}98.18 \\
\pm 1.87\end{array}$ & $\begin{array}{r}98.44 \\
\pm 0.82\end{array}$ \\
\hline BNCR & $\begin{array}{l}218.89 \\
\pm 0.71\end{array}$ & $\begin{array}{l}238.18 \\
\pm 1.04\end{array}$ & $\begin{array}{l}-29.57 \\
\pm 1.94\end{array}$ & $\begin{array}{l}-22.58 \\
\pm 0.88\end{array}$ & $\begin{array}{c}5.42 \\
\pm 0.07\end{array}$ & $\begin{array}{c}4.01 \\
\pm 0.05\end{array}$ & ------ & ------ & ------ & ------ \\
\hline NCMT & $\begin{array}{l}273.57 \\
\pm 1.57\end{array}$ & $\begin{array}{l}281.03 \\
\pm 1.35\end{array}$ & $\begin{array}{l}-31.95 \\
\pm 1.33\end{array}$ & $\begin{array}{l}-27.48 \\
\pm 0.91\end{array}$ & $\begin{array}{c}4.38 \\
\pm 0.08\end{array}$ & $\begin{array}{c}3.46 \\
\pm 0.11\end{array}$ & 84.11 & 85.43 & $\begin{array}{l}99.29 \\
\pm 1.66\end{array}$ & $\begin{array}{l}97.05 \\
\pm 1.3\end{array}$ \\
\hline $\mathrm{BNCT}$ & $\begin{array}{l}232.85 \\
\pm 0.85\end{array}$ & $\begin{array}{c}236.85 \\
\pm 0.38\end{array}$ & $\begin{array}{l}-30.01 \\
\pm 0.11\end{array}$ & $\begin{array}{l}-29.73 \\
\pm 1.78\end{array}$ & $\begin{array}{c}5.67 \\
\pm 0.04\end{array}$ & $\begin{array}{c}4.31 \\
\pm 0.09\end{array}$ & ------ & ----- & ------ & ------ \\
\hline
\end{tabular}

All samples showed a polydispersity index lower than $0.25 .{ }^{\mathrm{b}}$ Values represent the average between the 3 batches. Nanocapsules of mupirocin and rosemary oil (NCMR). Nanocapsules of mupirocin and caprylic/capric triglyceride oil (NCMT). Unloaded nanocapsules of rosemary oil (BNCR). Unloaded nanocapsules of caprylic/capric triglyceride oil (BNCT).

under both conditions (room temperature and $40{ }^{\circ} \mathrm{C}$ ). All values were negative, which confirms the stability of nanocapsules. A zeta potential value around $\pm 30 \mathrm{mV}$ is assumed to be good for formulations (Kumar et al., 2015). The negative potential values of the samples are related to the presence of polysorbate 80 , presenting a negative surface density of charge (Marchiori et al., 2010).

\section{CONCLUSIONS}

The rosemary and caprylic/capric triglyceride oils were used as oily core for the formulations. The nanoparticles showed adequate particle size, monomodal size distributions and low polydispersity index. All samples showed a reduction of $\mathrm{pH}$ value after storage at 40 ${ }^{\circ} \mathrm{C}$. On the other hand, the formulations showed adequate zeta potential according to the literature and appropriate quantity of mupirocin. The proposed analytical method was linear, selective for both oils, precise, accurate and robust for the determination of MUP-loaded polymeric nanocapsules, showing that it is a useful method for quality control of the proposed delivery system. The results of the present study showed promising data for the development of a new formulation containing MUP and rosemary oil in an attempt to increase the activity of MUP against Staphylococcus aureus.

\section{ACKNOWLEDGMENTS}

This research was supported by Projects 447548/2014-0 and 401069/2014-1 of the Conselho Nacional de Desenvolvimento Científico e Tecnológico (CNPq - Brazil). J. B. Rubenick thanks CAPES (Brazil) for the Master's fellowship.

\section{REFERENCES}

A G ÊNCI A NACIONAL DE VIGILÂNCIA SANITÁRIA. ANVISA. Resolução RE n.899, de 29 de maio de 2003. Guia para validação de métodos analíticos e bioanalíticos. Available from: <http:// portal.anvisa.gov.br/documents/33836/349509/ Consolidado\%2Bde\%2Bnormas $\% 2$ BCOBIO. pdf/3122249b-48cb-47aa-be78-76f3129a62ba>. Access on: May 28, 2015. 
AMRUTIYA, N.; MADAN, M.; BAJAJ, A. Development and validation of RP-HPLC method for simultaneous estimation of prednicarbate, mupirocin and ketoconazole in topical dosage forms. J. Anal. Chem., v.65, p.1148-1154, 2010.

BERG, O.A. Advanced delivery system for skin and burns therapy: mupirocin as an antibacterial model drug. Norway, 2011. 90p. Master Thesis - University of Tromso.

BRITISH Pharmacopoeia. London: The Stationery Office, 2012. v.2, p.1501-1503.

CHAN, C.C.; LEE, Y.C.; LAM, H.; ZHANG, X., (Eds). Analytical method validation and instrument performance verification. Hoboken: John Wiley, 2004. 303p.

COMIN, V.M.; LOPES, L.Q.S.; QUATRIN, P.M.; SOUZA, M.E.; BONEZ, P.C.; PINTOS, F.G.; RAFFIN, R.P.; VAUCHER, R.; MARTINEZ, D.S.T.; SANTOS, R.C.V. Influence of Melaleuca alternifolia oil nanoparticles on aspects of Pseudomonas aeruginosa biofilm. Microb. Pathog., v.93, p.120-125, 2016.

COUVREUR, P.; BARRETT, G.; FATTAL, E.; LEGRAND, P.; VAUTHIER, C. Nanocapsule technology: a review. Crit. Rev. Ther. Drug Carrier Syst., v.19, p.99-134, 2002.

ECHEVARRÍA, L.; BLANCO-PRÍETO, M.J.; CAMPANERO, M.A.; SANTOYO, S.; YGARTUA, P. Development and validation of a liquid chromatographic method for in vitro mupirocin quantification in both skin layers and percutaneous penetration studies. J. Chromatogr. B., v.796, p.233-241, 2003.

EPHREM, E.; GREIGE-GERGES, H.; FESSI, H.; CHARCOSSET, C. Optimisation of rosemary oil encapsulation in polycaprolactone and scale-up of the process. J. Microencapsul., v.31, p.746-753, 2014.

FESSI, H.; PUISIEUX, F.; DEVISSAGUET, J.P.; AMMOURY, N.; BENITA, S. Jejunal absorption, pharmacological activity, and pharmacokinetic evaluation of indomethacin-loaded poly(d,l-lactide) and poly(isobutylcyanoacrylate) nanocapsules in rats. Int. J. Pharm., n.55, p.R1-R4, 1989.
HARTER, A.P.G.; MOTTA, M.H.; BARROS, J.G.; RIBEIRO, R.F.; ADAMS, A.I.H.; SCHAFFAZICK, S.R.; SILVA, C.B. Desenvolvimento de um método para a determinação de tioconazol associado a nanocápsulas poliméricas por cromatografia líquida. Quim. Nova, v.37, p.996-999, 2014.

IANNITELLI, A.; GRANDE, R.; STEFANO, A.; GIULIO, M.; SOZIO, P.; BESSA, L.J.; LASERRA, S.; PAOLINI, C.; PROTASI, F.; CELLINI, L. Potential antibacterial activity of Carvacrol-Loaded poly (DL-Lactide-coGlycolide) (PLGA) Nanoparticles against microbial biofilm. Int. J. Mol. Sci., v. 12, p.5039-5051, 2011.

INSTITUTO NACIONAL DE METROLOGIA, NORMALIZAÇÃO E QUALIDADE INDUSTRIAL. INMETRO. DOQ-CGCRE-008: orientações sobre validação de métodos de ensaios químicos. 2007. Available from: http://www.inmetro.gov.br/sidoq/arquivos/cgcre/doq/ doq-cgcre-8_02.pdf. Access on: Feb. 26, 2016.

INTERNATIONAL CONFERENCE ON HARMONISATION. ICH. Quality Guidelines. View All Quality Guidelines. Q2 Analytical Validation. Q2 (R1) Validation of analytical procedures: text and methodology. 2005. Available from: <http://www.ich.org/fileadmin/Public_Web_Site/ ICH_Products/Guidelines/Quality/Q2_R1/Step4/Q2_R1 Guideline.pdf>. Access on: Feb. 26, 2016.

JAGOTA, N.K.; STEWART, J.T.; WARREN, F.W.; JOHN, P.M. STABILITY OF MUPIROCIN OINTMENT (BACTROBAN) ADMIXED WITH OTHER PROPRIETARY DERMATOLOGICAL PRODUCTS. J. Clin. Pharm. Ther., v.17, p.181-184, 1992.

JAIN, P.; JAIN, S.; PRASAD, K.N.; JAIN, S.K.; VYAS, S.P. Polyelectrolyte coated multilayered liposomes (nanocapsules) for the treatment of Helicobacter pylori infection. Mol. Pharm., v.6, p.593-603, 2009.

KUMAR, S.; CHUAHAN, N.; KUMAR, M.G.R.; DILBAGHI, N. Development and evaluation of alginatechitosan nanocapsules for controlled release of acetamiprid. Int. J. Biol. Macromolec., v.81, p.631-637, 2015.

MALLIN, M.; VAINIO, H.; KARJALAINEM, K.; SEPPALA, J. Biodegradable lactone copolymers. II. Hydrolytics study of $\varepsilon$-caprolactone and lactide copolymers. J. Appl. Polym. Sci., v.59, p.1289-1298, 1996. 
MARCHIORI, M.L.; LUBINI, G.; DALLA NORA, G.; FRIEDRICH, R.B.; FONTANA, M.C.; OURIQUE, A.F.; BASTOS, M.O.; RIGO, L.A.; SILVA, C.B.; TEDESCO, S.B.; BECK, R.C.R. Hydrogel containing dexamethasoneloaded nanocapsules for cutaneous administration: preparation, characterization, and in vitro drug release study. Drug Develop. Ind. Pharm., v.36, p.962-971, 2010.

MARTINDALE: the complete drug reference. 37. ed. London: Pharmaceutical Press, 2011.

MARYAM, I.; HUZAIFA, U.; HINDATU, H.; ZUBAIDA, $\mathrm{S}$. Nanoencapsulation of essential oils with enhanced antimicrobial activity: a new way of combating antimicrobial resistance. J. Pharm. Phytochem., v.4, p.165-170, 2015.

MORA-HUERTAS, C.E.; FESSI, H.; ELAISSARI, A. Polymer-based nanocapsules for drug delivery. Int. J. Pharm., v.385, p.113-142, 2010.

NOGUEIRA, R.; WOLLINGER, W.; SILVA, T.E.; OLIVEIRA, L.M.; MOREIRA, G.F.; BARIN, J.S.; LAPORTA, L.V.; MESKO, M.F.; BITTENCOURT, C.F.; RODRIGUES, J.M.; CUNHA, V.S. Validation of a liquid chromatographic method for determination of related substances in a candidate certified reference material of captopril. Braz. J. Pharm. Sci., v.47, p.351-362, 2011.

POOVELIKUNNEL, T.; GETHIN, G.; HUMPHREYS, H. MUPIROCIN RESISTANCE: CLINICAL IMPLICATIONS AND POTENTIALALTERNATIVES FOR THE ERADICATION OF MRSA. J. ANTIMICROB. Chemother., v.70, p.2681-2692, 2015.

RIBANI, M.; BOTTOLI, C.; COLlinS, C.; JARDIM, I. Validação em métodos cromatográficos e eletroforéticos. Quim. Nova, v.27, p.771-780, 2004.

SCHAFFAZICK, S.R.; GUTERRES, S.S.; FREITAS, L.L.; POHLMANN, A.R. Caracterização e estabilidade físicoquímica de sistemas poliméricos nanoparticulados para administração de fármacos. Quim. Nova, v.26, p.726-737, 2003.
SHABIR, G.A. Validation of HPLC methods for pharmaceutical analysis: understanding the differences and similarities between validation requirements of the U.S. Food and Drug Administration, the U.S. Pharmacopoeia and the International Conference on Harmonization. J. Chromatogr. A, v.987, p.57-66, 2003.

SHAILESH, T.; KULKARNI, P. K. Development and evaluation of mupirocin loaded liposomal hydrogels for diabetic wound healing properties. Ind. J. Adv. Chem. Sci., v. 2, p. $42-45,2014$.

SUTHERLAND, R.; BOON, R.J.; GRIFFIN, K.E.; MASTERS, P.J.; SLOCOMBE, B.; WHITE, A.R. Antibacterial activity of mupirocin (pseudomonic acid): a new antibiotic for topical use. Antimicrob. Agents. Chemother., v.27, p.495-498, 1985.

UNITED STATES PHARMACOPEIAL. USP. Pharmacopeia of the United States of America: USP35, The National Formulary: NF30. Rockville: United States Pharmacopeial Convention, 2012. v.3, p.3962-3963.

THOMAS, C.M.; HOTHERSALL, J.; WILLIS, C.L.; SIMPSON, T.J. Resistance to and synthesis of the antibiotic mupirocin. Nat. Rev. Microbiol., v.8, p.281-289, 2010.

YOUDEN, W.; STEINER, E. Statistical manual of AOAC. Washington: AOAC, 1975. 88p.

WU, L.; ZHANG, J.; WATANABE, W. Physical and chemical stability of drug nanoparticles. Adv. Drug. Deliv. Rev., v.63, p.456-469, 2011.

ZILI, Z.; SFAR, S.; FESSI, H. Preparation and characterization of poly- $\varepsilon$-caprolactone nanoparticles containing griseofulvin. Int. J. Pharm., v.294, p.261-267, 2005.

Received for publication on $06^{\text {th }}$ June 2015 Accepted for publication on $03^{\text {rd }}$ November 2016 